\title{
Criteria indicators of formation of economic competence of system of the general education
}

\author{
Marina G. Sergeeva ${ }^{1, *}$, and Ekaterina E. Nikitina ${ }^{2}$ \\ ${ }^{1}$ ISED RAE, Center of Social and Liberal Education, 105062, Moscow, Russia \\ 2 ISED RAE, Laboratory of history of pedagogics and education, 105062, Moscow, Russia
}

\begin{abstract}
This article analyses the technology of determination of level of formation of economic competence of school students taking into account the developed criteria. The research is fulfilled on the basis of the formulated determination of economic competence and its structure (informative; motivational; activity). Each criterion corresponds with certain indicators reflecting degree of formation of separately taken component.
\end{abstract}

We regard economic competence as a result of all system of economic education and education of school students at a certain grade level as integrated quality of the identity of the trainee, including initiative, enterprise, independence of decision-making, criticality of thinking, etc.

Economic competence is based on the set of informative, activity, emotional and valuable and creative components of economic training of school students.

In its structure it is possible to single out the following components:

- theoretical component - the scientific fundamentals of modern economy at the international, regional and local levels assuming competence of understanding of value of production of material benefits as bases of economic life; ability to distinguish the income which is brought in by various factors of production; ability to analyze efficiency of various versions of the economic decision and to make the effective choice in the conditions of limited resources; understanding of essence of market balance as results of interaction of laws of supply and demand, competition, need of state regulation of economy; features of market system of managing, its advantages and shortcomings, etc.;

- practical component - the economic competences defining ability to assess economic situation and make independent decisions when economic problems emerge; providing the mechanism of social and economic adaptation; creating prerequisites for the choice of the sphere of economic activity; defining result and quality of the economic relations, level of economic activity; forming rules of economic behavior, level of economic and financial security; providing accurate achievements of goals, registration of economically reasonable decisions, etc.

Level of economic competences of trained (UEK) was determined by three criteria: cognition; motivation; activity [3].
Each criterion is described by means of the system of the empirical indicators reflecting degree of formation of a separately taken component.

On the basis of the studied and analyzed scientific, pedagogical and special literature, we have defined about seven necessary and sufficient indicators for each criterion. Selecting indicators, we took into account the need to consider, at least, two important conditions: informational content of an indicator and possibility of its quantitative and high-quality interpretation.

The indicators of the criteria mentioned above, i.e. the instruments by which those are measured, are the following [2]:

Cognition:

- knowledge of economic terms and concepts, ability to explain their sense;

- manifestation of interest in current economic problems;

- ability to plan expenses;

- application of knowledge for the characteristic of economic problems;

- ability to correctly analyze and establish relationships of cause and effect of economic problems;

- ability to detect regularity of functioning of market mechanisms;

- application of economic knowledge for the solution of stereotypic and non-standard tasks.

Motivation:

- austerity policy in the educational organization and at home (thriftiness);

- planning and regulation of the behavior in economic situations (independence);

- calculation of volume of work and costs of its performance (rationality);

- quality performance of the charged work (diligence);

- efficiency of work performance and solution of problem economic situations (enterprise);

\footnotetext{
Corresponding author: sergeeva198262@mail.ru
} 
- need for economic activity as prerequisites of sustainable development of society and production;

- understanding of the need of economic competence formation.

Activity:

- ability to analyze economic situations and to find possibilities to increase their efficiency;

- ability to transfer knowledge to practical activities;

- need of the external management for economic activity;

- ability to place priorities for achievement of result in economic activity;

- manifestation of independence in target-setting, in finding ways to achieve them;

- ability to model economic activity;

- preference of innovative and/or short-term projects.

Table 1. Cognitive criterion (cognition), the economic competences which are trained $(\mathrm{K})$

\begin{tabular}{|l|l|}
\hline No. & Indicator \\
\hline K1 & $\begin{array}{l}\text { knowledge of economic terms and } \\
\text { concepts, ability to explain their sense }\end{array}$ \\
\hline K2 & $\begin{array}{l}\text { manifestation of interest in current } \\
\text { economic problems }\end{array}$ \\
\hline K3 & $\begin{array}{l}\text { ability to plan expenses } \\
\text { application of knowledge for the } \\
\text { characteristic of economic problems }\end{array}$ \\
\hline K5 & $\begin{array}{l}\text { ability to correctly analyze and } \\
\text { establish relationships of cause and } \\
\text { effect of economic problems }\end{array}$ \\
\hline K6 & $\begin{array}{l}\text { ability to detect regularity of } \\
\text { functioning of market mechanisms }\end{array}$ \\
\hline K7 & $\begin{array}{l}\text { application of economic knowledge } \\
\text { for the solution of stereotypic and } \\
\text { non-standard tasks }\end{array}$ \\
\hline
\end{tabular}

Table 2. Motivational criterion (motivation), economic competences of trained $(\mathrm{M})$

\begin{tabular}{|l|l|}
\hline No. & \multicolumn{1}{|c|}{ indicator } \\
\hline M1 & $\begin{array}{l}\text { austerity policy in the educational } \\
\text { organization and at home (thriftiness) }\end{array}$ \\
\hline M2 & $\begin{array}{l}\text { planning and regulation of the } \\
\text { behavior in economic situations } \\
\text { (independence) }\end{array}$ \\
\hline M3 & $\begin{array}{l}\text { calculation of volume of work and } \\
\text { costs of its performance (rationality) }\end{array}$ \\
\hline M4 & $\begin{array}{l}\text { quality performance of the charged } \\
\text { work (diligence) }\end{array}$ \\
\hline M5 & $\begin{array}{l}\text { efficiency of work performance and } \\
\text { solution of problem economic } \\
\text { situations (enterprise) }\end{array}$ \\
\hline M6 & $\begin{array}{l}\text { need for economic activity as } \\
\text { prerequisites of sustainable } \\
\text { development of society and } \\
\text { production }\end{array}$ \\
\hline M7 & $\begin{array}{l}\text { understanding of need of economic } \\
\text { competence formation }\end{array}$ \\
\hline
\end{tabular}

Table 3. Activity criterion (activity), the economic competences which are trained (D)

\begin{tabular}{|l|l|}
\hline No. & \multicolumn{1}{|c|}{ indicator } \\
\hline D1 & $\begin{array}{l}\text { ability to analyze economic situations } \\
\text { and to find possibilities to increase } \\
\text { their efficiency }\end{array}$ \\
\hline D2 & $\begin{array}{l}\text { ability to transfer knowledge to } \\
\text { practical activities }\end{array}$ \\
\hline D3 & $\begin{array}{l}\text { need of the external management for } \\
\text { economic activity }\end{array}$ \\
\hline D4 & $\begin{array}{l}\text { ability to place priorities for } \\
\text { achievement of result in economic } \\
\text { activity }\end{array}$ \\
\hline D5 & $\begin{array}{l}\text { manifestation of independence in } \\
\text { target-setting, in finding ways to } \\
\text { achieve them }\end{array}$ \\
\hline D6 & $\begin{array}{l}\text { ability to model economic activity } \\
\text { preference of innovative and/or short- } \\
\text { term projects }\end{array}$ \\
\hline D7
\end{tabular}

The general indicator is determined by each parameter:

$\mathrm{TO}=\mathrm{K} 1+\mathrm{K} 2+\ldots \mathrm{K} 7 ; \mathrm{M}=\mathrm{M} 1+\mathrm{SQ} \cdot \mathrm{M}+\ldots \mathrm{M} 7$; $\mathrm{D}=\mathrm{D} 1+\mathrm{D} 2+\ldots \mathrm{D} 7$.

We are interested in the general result of efficiency of formation of the economic competences which are trained (tab. 4). The integrative indicator (UEK) was calculated as an arithmetic average.

The total point of the general result changes ranging from 0 to 10 .

Table 4. The summary table of estimates of formation of indicators of the economic competences which are trained

\begin{tabular}{|c|c|c|c|c|c|c|c|c|c|}
\hline $\begin{array}{c}\text { No. of a } \\
\text { payment } \\
\text { order }\end{array}$ & $\begin{array}{c}\text { FULL } \\
\text { NAME } \\
\text { student }\end{array}$ & \multicolumn{6}{|c|}{ Points on indicators } & $\begin{array}{c}\text { Formation } \\
\text { level }\end{array}$ \\
\hline & & & & & & & & & \\
\hline & & & & & & & & & \\
\hline & & & & & & & & & \\
\hline
\end{tabular}

Considering the fact that the level of economic competences is most often average and less often high, we have established uneven intervals at group of points on levels of economic competences, relying on A.A. Kyveryalga's technique. According to this technique, low level is determined by $25 \%$ deviation from an average by the range of estimates of point. Then the assessment from an interval from $\mathrm{R}(\mathrm{min})$ to $0,25 \mathrm{R}(\max )$ allows to state the low level of economic competences of students, and the high level is indicated by marks exceeding $75 \%$ of the maximum. On the basis of the above technique, levels of economic competences have been determined by the following intervals (table 5). Determination of level of the economic competences of the trained people was carried out by comparison of their total point (according to table 5) with the presented scale. 
Table 5. Intervals of levels, the economic competences which are trained

\begin{tabular}{|c|c|c|}
\hline $\begin{array}{c}\text { No. of a } \\
\text { payment } \\
\text { order }\end{array}$ & $\begin{array}{c}\text { Intervals of an } \\
\text { integrative indicator } \\
\text { (point) }\end{array}$ & $\begin{array}{c}\text { Level of } \\
\text { economic } \\
\text { competence }\end{array}$ \\
\hline 1 & $10-8$ & high \\
\hline 2 & $7-4$ & average \\
\hline 3 & $3-0$ & low \\
\hline
\end{tabular}

Application of mark estimates has allowed to determine effectiveness ratio of formation of the economic competences which are trained in educational process by each of indicators. This coefficient is determined by a formula:

$\mathrm{Ke}=$ actual number of points

greatest possible number of points

Having adapted V.P. Bespalko [1] technique, we have defined a degree of efficiency of economic competences formation of students of educational process as follows (table 6):

Table 6. Efficiency degree of process of formation of the trained economic competences

\begin{tabular}{|c|c|}
\hline $\begin{array}{c}\text { Value of coefficient } \\
\text { efficiency }(\mathrm{Ke})\end{array}$ & $\begin{array}{c}\text { Degree of efficiency of } \\
\text { formation of economic } \\
\text { competence }\end{array}$ \\
\hline $0,8 \leq \mathrm{K} \leq 1,0$ & high \\
\hline $0,6 \leq \mathrm{K}<0,8$ & average \\
\hline less 0,6 & low \\
\hline
\end{tabular}

The article includes the materials received as a result of performance of the state task on a subject of the research "Scientific and Pedagogical Approaches to Formation of Economic Competence of the Courses of Economy, Social Science and Geography Which Are Trained when Studying".

\section{References}

1. N.P. Zalkina, and M.G. Sergeeva, Creation of professional career in a context of competence-based approach (Regional financial and economic institute, Kursk, 2013) [In Rus]

2. G.E. Koroleva, M.G. Sergeyeva, Information and communication technologies in economic education of seniors (Regional financial and economic institute, Kursk, 2016) [In Rus]

3. M.G. Sergeyeva, Didactic principle of development of continuous economic education (Regional financial and economic institute, Kursk, 2012) [In Rus] 